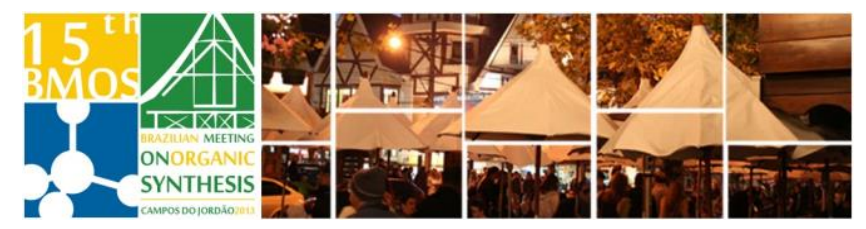

\title{
Synthesis of Carbonohydrazideamide, Carbonohydrazidethioamide with potential biological activity
}

\author{
Camila S. S. Tozatti ${ }^{1 \star}$, Edson A. dos Santos ${ }^{2}$, Narcimário P. Coelho ${ }^{1}$, Maria Cristina \\ P. dos Santos ${ }^{1}$, Michael J. V. da Silva ${ }^{1}$, Davana S. Gonçalves ${ }^{1}$, Ernani A. Basso' \\ ${ }^{1}$ Universidade Estadual de Maringá, CEP 87.020-900, Maringá, PR, Brazil. \\ ${ }^{2}$ Universidade Tecnológica Federal do Paraná, CEP 86.812-460, Apucarana, PR, Brazil.
}

*e-mail corresponding author: csstozatti2@uem.br

Keywords: Carbonohydrazides, Carbonohydrazideamide, Carbonohydrazidethioamide

\section{INTRODUCTION}

Semicarbazones,

carbonohydrazides, thiosemicarbazides and semicarbazides are reported to possess a wide range of biological activities, such as antimicrobial, fungicidal and antitumor. ${ }^{1-6}$ However, to the best of our knowledge, carbonohydrazideamide

and carbonohydrazidethioamide are not reported anywhere, despite the structural similarity with the functional groups mentioned above (figure 1). With the aim of developing a route for biologically active compounds, herein we report the synthesis of a series of Carbonohydrazideamide and carbonohydrazidethioamide.

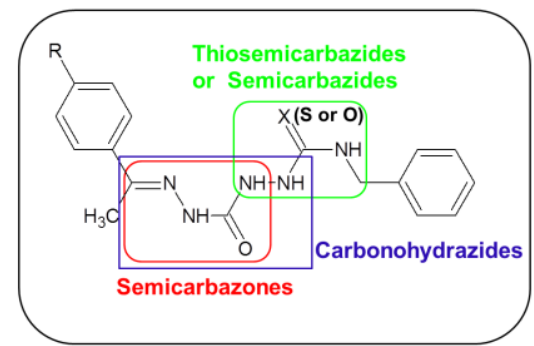

Figure1. Carbonohydrazideamide or carbonohydrazidethioamide and its relationship with other functional groups.

\section{RESULTS AND DISCUSSION}

The general schematic representation describing the routes of syntheses is presented in Scheme 1. Carbonohydrazides $(1-8)$ were prepared by the condensation of carbohydrazide with respective acetophenone in the presence of concentrated hydrochloric acid in water-ethanol for $12 \mathrm{~h}^{7}$ Hydrazinacarboamidas (9-16) and hidrazinacarbotioamidas (17-24) are synthesized by reaction of carbonohydrazides (1-8) with benzyl isocyanate or benzyl isothiocyanate in DMSO for 1 h.

The structures of the products were confirmed by ${ }^{1} \mathrm{H}$ and ${ }^{13} \mathrm{C}$ NMR spectra. The intermediates 1-8 and 924 were isolated with $80-98 \%$ yields.

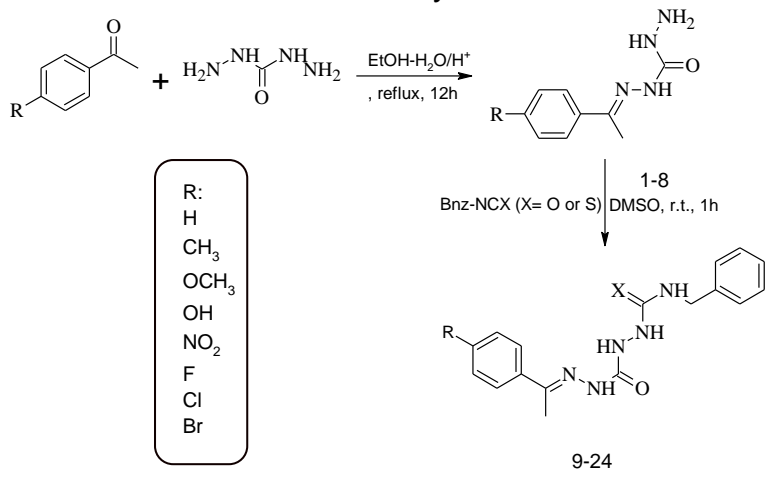

Scheme 1. Synthesis of Carbonohydrazideamide or carbonohydrazidethioamide

\section{CONCLUSION}

Compounds 1-24 were obtained with high yields, among these, the compounds 9-24 are inedited and will be evaluated as antimicrobial, fungicidal and antitumor.

\section{ACKNOWLEDGEMENTS}

The authors thank the financial support from CNPq, CAPES and Fundação Araucária.

\section{REFERENCES}

[1] Jafri, L. et al. Chem Biol Drug Des 2012, 79,950-959; [2] Gammal, O.A. E. et al. Journal of Molecular Structure 2012, 1020, 6-15; [3] Leite, A.C.L. et al. Acta Farm. Bonaerense 2004, 23, 117-122; [4] Yousef, T.A. et al. Int. J. Med. Med. Sci 2011, 3, 37-46; [5] Gokce, M. et al. Journal of Faculty of Pharmacy of Gazi University 2000, 17, 61-70; [6] Umamatheswari, S. et al. European Journal of Medicinal Chemistry 2011, 46, 1415-1424; [7] Li, Z. et al. Synthetic Communications 2006, 36, 2613-2619. 